\title{
Variability in Water Loss Patterns of New Guinea Impatiens Cultivars and Breeding Selections
}

\author{
Mark S. Strefeler and Robert-Jan W. Quené \\ Department of Horticultural Science, University of Minnesota, 305 Alderman Hall, 1970 Folwell \\ Avenue, Saint Paul, MN 55108
}

\begin{abstract}
Additional index words. transpiration rate, drought tolerance, Impatiens hawkerii
Abstract. Six commercial cultivars (Anna, Aurore, Danhill, Danlight, Melanie, and Thelca), one drought tolerant cultivar (Orangeade), nine breeding selections, and one check genotype of Impatiens hawkeri Bull were evaluated for differences in drought tolerance based on water loss and time to wilt. The six commercially available cultivars had significantly higher mean water loss than the breeding selections and 'Orangeade'. These cultivars wilted in 5.11 vs. 7.33 days for 'Orangeade' and 9.10 days for the breeding selections. These results suggest that sufficient variability exists in New Guinea impatiens germplasm for the reduction of water loss to improve drought tolerance. Regression analysis revealed that total transpirational water loss 96 hours after withholding water was an excellent predictor of the time to wilting (a simple measure of drought tolerance) after water was withheld $\left(R^{2}=0.95\right)$. Thus, a simple, efficient and objective method for selection of drought tolerant genotypes has been developed for New Guinea impatiens. A comparison of offspring to parental genotypes showed that after only one cycle of selection, water loss was significantly reduced by $>30 \%$. These results suggest that there is sufficient genetic variability present for the development of more drought tolerant cultivars.
\end{abstract}

New Guinea impatiens have been increasing in popularity in the United States since their introduction in 1972. New Guinea impatiens were promoted as a flowering potted and bedding plant. Much of the popularity of New Guinea impatiens is due to large flower size, wide range of flower colors, and superb foliage, which can range in color from light to dark green to maroon, in addition to a wide variety of leaf variegation patterns and solid leaf colors.

New Guinea impatiens were marketed as being more heat and sun tolerant than the already popular Impatiens wallerana (Armstrong, 1974); however, New Guinea impatiens had a high water requirement (Kaczperski et al, 1989; Mack, 1989; Martin, 1984). Under high light and temperatures, New Guinea impatiens may require water several times a day to prevent water stress. Water-stressed New Guinea impatiens will drop their leaves and flowers very rapidly (Kaczperski and Carlson, 1989; Martin, 1984).

Little effort has been made toward improving drought tolerance of New Guinea impatiens. Improvement of the water-use efficiency of New Guinea impatiens would be of economic value to growers and consumers and may increase the use and marketability of this floral crop.

The current commercial cultivars can be traced back to the 25 plants collected and brought to the United States in 1970 by Winters (1973). Thus, New Guinea impatiens cultivars have originated from a small number of plants. Issues to be addressed in developing a breeding program should concern variability for drought tolerance within the New Guinea impatiens germplasm and the possibility that selection will significantly increase drought tolerance. To address these issues, cultivars and breeding lines were inter-mated to create segregating $F_{1}$ populations. Plants that exhibited leaf characteristics reported to be related to reduced water loss, namely thick, glossy leaves (Begg, 1980; Ehleringer, 1980) were selected from the segregating $F_{1}$ populations and tested for drought tolerance. Plants were selected qualitatively based on plant appearance. Cuticle and leaf thickness was not quantified using physical measurements.

Received for publication 6 July 1994, Accepted for publication 13 Dec. 1994. Scientific Journal Series paper no. 21,104. Minnesota Agricultural Experiment Station, St. Paul, The cost of publishing this paper was defrayed in part by the payment of page charges. Under postal regulations, this paper therefore must be hereby marked advertisement solely to indicate this fact.
The purpose of this study was to assess drought tolerance among New Guinea impatiens germplasm and to evaluate effectiveness of selection-based plant appearance (qualitative method) to identify drought-tolerant plants for further testing using quantitative selection methods.

\section{Materials and Methods}

Six commercial cultivars, 'Orangeade', a cultivar identified as drought tolerant from the Univ. of Iowa and twelve selections, eleven with putative low water loss characteristics based on qualitative assessment of leaf morphology and one with putative high water loss check (Table 1), from the Univ. of Minnesota New Guinea impatiens breeding program were used in this study. Cuttings were rooted in 5 $\times 5 \times 3.8$-cm rockwool cubes (Agro Dynamics, New Brunswick, N.J.). After rooting, six cuttings of each genotype were selected based on uniformity of rooting and size (number of nodes and number of fully expanded leaves) among and within all genotypes to reduce variability caused by differences in plant size. The cuttings were irrigated to saturation using water (no added nutrients) and the rockwool cubes were wrapped in plastic to prevent water loss due to evaporation and weighed. As a control, six rockwool cubes (per replicate) without plants were saturated with water, wrapped in plastic, and treated the same as the cuttings in rockwool. All plant material was placed in a growth chamber under a 14-h photopenod ( 0500 to $1900 \mathrm{HR}$ ) and 26/20 C day/night temperature regime with $300 \mu \mathrm{mol} \cdot \mathrm{s}^{-1} \cdot \mathrm{m}^{-2} 1$ ight provided by cool-white fluorescent lamps and a relative humidity of $40 \%$. Rockwool was selected as the growing substrate due to its high uniformity in water-holding capacity and water availability to plants.

Plants and rockwool cubes were weighed every $6 \mathrm{~h}$ until all leaves on plants were wilted. Rockwool cubes that were saturated but did not hold cuttings were weighed every $6 \mathrm{~h}$ to determine the water loss due to evaporation over the course of this study. Total water loss was calculated by subtracting the measured weight taken at wilting from initial weight of the rockwool and cutting measured at the start of the experiment. Initial weights were taken at $1200 \mathrm{HR}(\mathrm{time}=0)$ and the first weight used to calculate water loss was taken at $1800 \mathrm{HR}$ (time= 6). Daily water loss was calculated by totaling the four water loss measurements over a $24-\mathrm{h}$ period. Times to wilt were determined by counting the number of days from application of water to wilting of 
Table 1. New Guinea impatiens cultivars and genotypes used to assess differences in transpiration rate, water loss, and time to wilt.

\begin{tabular}{|c|c|c|c|}
\hline Cultivar/Line & Comments & Line & Comments \\
\hline$A n n a^{2}$ & $\begin{array}{c}\text { Bull Series } \\
\text { (Pelfi by Fisher, Homestead, Fla.) }\end{array}$ & RQ-43-6 & $\begin{array}{l}\text { Tolerant selection } \\
\text { (Aurore x Lambada) }\end{array}$ \\
\hline Aurore $^{z}$ & $\begin{array}{c}\text { Pure Beauty Series } \\
\text { (Kientzler, Paul Ecke Ranch, Encinitas, Calif.) }\end{array}$ & RQ-105-2 & $\begin{array}{c}\text { Tolerant selection } \\
\text { (Flamenco x Orangeade) }\end{array}$ \\
\hline Danhill $^{2}$ & $\begin{array}{l}\text { Danzinger Series } \\
\text { Pelfi by Fisher }\end{array}$ & RQ- 105-4 & $\begin{array}{c}\text { Tolerant selection } \\
\text { (Flamenco x Orangeade) }\end{array}$ \\
\hline Danlight $^{2}$ & $\begin{array}{l}\text { Danzinger Series } \\
\text { (Pelfi by Fisher) }\end{array}$ & RQ-105-5 & $\begin{array}{c}\text { Tolerant selection } \\
\text { (Flamenco x Orangeade) }\end{array}$ \\
\hline Melanie $^{z}$ & $\begin{array}{l}\text { Bull Series } \\
\text { (Pelfi by Fisher) }\end{array}$ & RQ-130-1 & $\begin{array}{l}\text { Tolerant selection } \\
\text { (Anneaa x 8998-3) }\end{array}$ \\
\hline Thelca $^{2}$ & $\begin{array}{c}\text { Pure Beauty } \\
\text { (Kientzler Series) }\end{array}$ & RQ-130-2 & $\begin{array}{l}\text { Tolerant selection } \\
\text { (Anneaa x 8998-3) }\end{array}$ \\
\hline Orangeade & $\begin{array}{l}\text { Iowa State University } \\
\text { (Tolerant cultivar) }\end{array}$ & RQ-79-1 & $\begin{array}{c}\text { Tolerant selection } \\
\text { (Orangeade x Flamenco) }\end{array}$ \\
\hline RQ-22-10 ${ }^{y}$ & $\begin{array}{l}\text { Susceptible check } \\
\text { (Celerio x Danshir) }\end{array}$ & RQ-79-4 & $\begin{array}{c}\text { Tolerant selection } \\
\text { (Orangeade } \mathbf{x} \text { Flamenco) }\end{array}$ \\
\hline RQ-124-3 & $\begin{array}{l}\text { Tolerant selection } \\
\text { (Doerte x Flamenco) }\end{array}$ & & \\
\hline
\end{tabular}

${ }^{2}$ Denotes commercial cultivars used in this study.

'Genotypes beginning with the letters, "RQ' are selections from the University of Minnesota New Guinea impatiens breeding program.

Table 2. Mean total water loss, leaf area, and days to wilting of seven cultivars and ten breeding selections of New Guinea impatiens.

\begin{tabular}{|c|c|c|c|c|}
\hline Line & $\begin{array}{l}\text { Transpiration rate } \\
\left(\mathrm{mg} \cdot \mathrm{cm}^{-2} \cdot \text { day }^{-1}\right)\end{array}$ & $\begin{array}{l}\text { Leaf area } \\
\left(\mathrm{cm}^{2}\right)\end{array}$ & $\begin{array}{c}\text { Average daily } \\
\text { water loss }\left(\mathrm{g} \cdot \mathrm{day}^{-1}\right)\end{array}$ & $\begin{array}{l}\text { Time to wilt } \\
\text { (days) }\end{array}$ \\
\hline RQ-22-10 (Check) & $214.8 \mathrm{a}^{2}$ & $111.4 \mathrm{a}$ & $19.5 \mathrm{a}$ & $4.25 \mathrm{a}$ \\
\hline Anna & $131.0 \mathrm{~b}$ & $169.2 \mathrm{~b}$ & $16.1 \mathrm{~b}$ & $4.25 \mathrm{a}$ \\
\hline Melanie & $152.4 \mathrm{~b}$ & $123.3 \mathrm{a}$ & $15.2 \mathrm{~b}$ & $4.75 \mathrm{a}$ \\
\hline Danlight & $196.3 \mathrm{~b}$ & $94.3 \mathrm{c}$ & $14.9 \mathrm{~b}$ & $4.50 \mathrm{a}$ \\
\hline Danhill & $211.2 \mathrm{ab}$ & $80.1 \mathrm{~cd}$ & $13.9 \mathrm{~b}$ & $5.25 \mathrm{a}$ \\
\hline Aurore & $146.2 \mathrm{~b}$ & $102.0 \mathrm{c}$ & $13.3 \mathrm{~b}$ & $5.75 \mathrm{a}$ \\
\hline Thelca & $121.9 \mathrm{~b}$ & $131.9 \mathrm{a}$ & $13.3 \mathrm{~b}$ & $5.75 \mathrm{a}$ \\
\hline RQ-124-3 & $186.7 \mathrm{~b}$ & $75.2 \mathrm{~d}$ & $13.2 \mathrm{~b}$ & $6.50 \mathrm{~b}$ \\
\hline Orangeade & $100.8 \mathrm{c}$ & $115.5 \mathrm{a}$ & $10.9 \mathrm{c}$ & $7.25 \mathrm{c}$ \\
\hline RQ-130-2 & $103.7 \mathrm{c}$ & $99.6 \mathrm{c}$ & $10.3 \mathrm{c}$ & $8.00 \mathrm{~d}$ \\
\hline RQ-43-6 & $116.2 \mathrm{c}$ & $88.8 \mathrm{c}$ & $10.2 \mathrm{c}$ & $8.25 \mathrm{~d}$ \\
\hline RQ-79-1 & $145.9 \mathrm{~b}$ & $64.8 \mathrm{e}$ & $9.5 \mathrm{c}$ & $9.25 \mathrm{e}$ \\
\hline RQ-105-2 & $85.7 \mathrm{~d}$ & $103.5 \mathrm{c}$ & $8.8 \mathrm{~d}$ & $9.50 \mathrm{e}$ \\
\hline RQ-79-4 & $108.7 \mathrm{c}$ & $81.7 \mathrm{~cd}$ & $8.8 \mathrm{~d}$ & $9.25 \mathrm{e}$ \\
\hline RQ-105-4 & $92.6 \mathrm{~d}$ & $92.4 \mathrm{c}$ & $8.7 \mathrm{~d}$ & $9.50 \mathrm{e}$ \\
\hline RQ-130-1 & $109.4 \mathrm{c}$ & $74.6 \mathrm{~d}$ & $7.8 \mathrm{~d}$ & $9.50 \mathrm{e}$ \\
\hline RQ-105-5 & $94.3 \mathrm{~d}$ & $76.2 \mathrm{~d}$ & $6.9 \mathrm{e}$ & $9.50 \mathrm{e}$ \\
\hline
\end{tabular}

the plant. Transpiration rate was determinedly calculating water loss per unit time per unit leaf area for each plant. Leaf area was determined by dehydrating wilted plants and then passing leaves through a portable leaf area meter (Li-3000; Li-Cor, Lincoln, Neb.) to obtain the total leaf area of each plant. The experiment was conducted over a 12-day period.

Stomatal densities were determined by painting the underside of leaves with clear nail polish to make a temporary impression of the leaf surface. The nail polish was then peeled off the leaves and stomates were counted using a microscope. The number of stomata visible in the field of view and the area of the field of view were used to calculate the stomatal density (number of stomates $/ \mathrm{cm}^{2}$ of leaf area), and there were five replicates per genotype. Stomatal size was measured as the length of the long axis of stomata using a micrometer.

The experimental design was a completely random design with two replicates; the experiment was replicated over time. Analysis of variance was used to determine differences in transpirational water loss between cultivars and breeding selections and to assess genetic variability among genotypes. Regression analysis was used to examine the relationships between leaf area, rate of water loss, and time to wilting of plants. Data analysis was performed using Systat for the Macintosh (Evansville, Ill.).

\section{Results and Discussion}

Mean water loss from saturated cubes was $<1.0 \%$ over the 10 days that each replicate of this experiment lasted (data not shown). Among the 12 control rockwool cubes (no plants), weight of dry cubes were not significantly different $(P<0.01)$ and the weights of saturated cubes were not significantly different $(P<0.01)$ within 
Table 3. Multivariate regression analysis of leaf area and transpiration rate on time to wilt for New Guinea impatiens.

\begin{tabular}{lrrrr}
\hline \hline Variable & Coefficient & \multicolumn{1}{c}{$\mathrm{SE}$} & \multicolumn{1}{c}{$t$ statistic } & $P(2$-tailed $)$ \\
\hline Constant & 13.1026 & 0.5875 & 22.303 & $<0.001$ \\
Leaf area (LA) & +.0156 & 0.0058 & -2.667 & 0.009 \\
Transpiration rate $(\mathrm{T})^{2}-0.3561$ & 0.0892 & -3.992 & $<0.001$ \\
LA $\times$ T & -0.0050 & 0.0010 & -5.125 & $<.001$ \\
$\left(R^{2}=0.918\right)$ & & & &
\end{tabular}

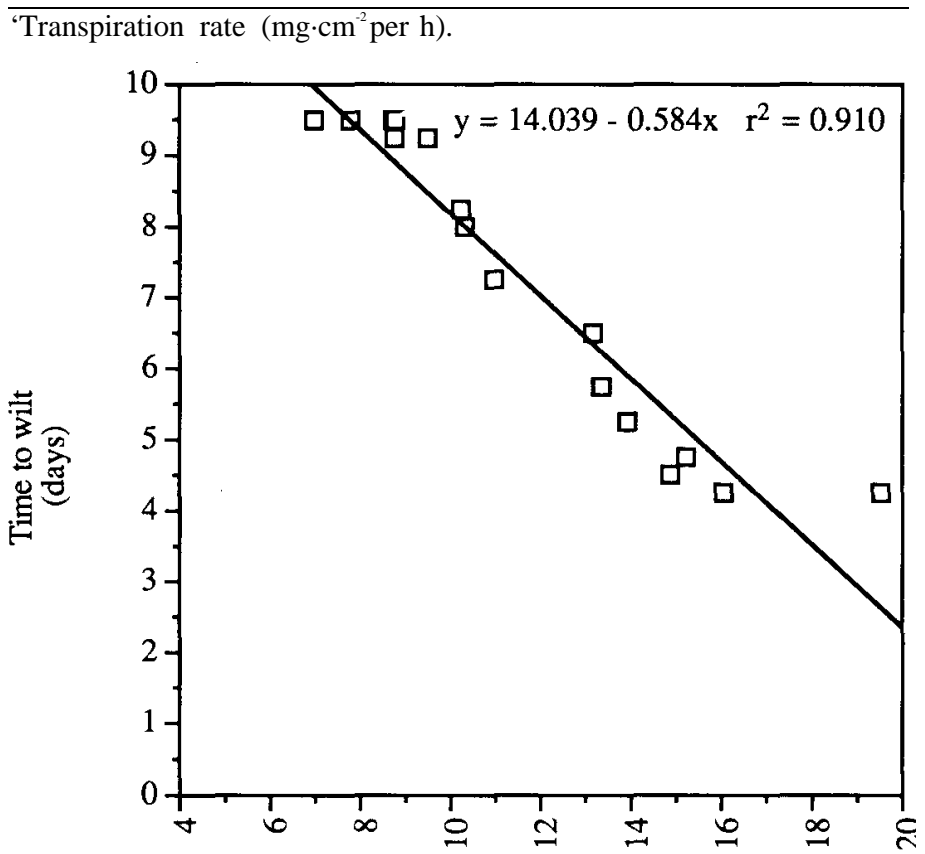

Water loss (g/day)

Fig. 1. Relationship between daily water loss and time to wilt for seven cultivars and ten breeding lines of New Guinea impatiens. Daily water loss was calculated as the fresh weight loss over a 24-h period, which began at $0600 \mathrm{HR}$, the start of the 14-h photoperiod, and ended at $0600 \mathrm{HR}$, the following morning, the end of the 10-h nyctoperiod.

a particular time period (data not shown). Thus, rockwool provided a uniform medium and water reservoir for plants in this study.

Plant genotypes differed significantly $(P<0.001)$ for time to wilt (days), leaf area (cm'), transpiration rate $\left(\mathrm{mg} \cdot \mathrm{cm}^{-2} \cdot \mathrm{h}^{-1}\right)$ and stomatal density (stomata/cm'). Genotype did not have a significant effect on total water loss $(P=0.075)$. This suggests that wilting occurred at similar substrate water potentials and that differences in the time to wilting were due to the regulation of water loss rather than differences in water uptake efficiency of root systems.

No significant differences were observed among the six commercial cultivars for time to wilt (Table 2). Cultivars varied significantly for transpiration rate $\left(\mathrm{mg} \cdot \mathrm{cm}^{-2} \cdot \mathrm{h}^{-1}\right)$, leaf area $\left(\mathrm{cm}^{2}\right)$ and rate of water loss per plant (g/day) (Table 2). Significant differences for all traits were observed among breeding selections and 'Orangeade' (Table 2).

Multivariate regression analysis revealed that leaf area, transpiration rat e, and their interaction accounted for most of the variation $\left(r^{2}=0.91\right)$ observed among genotypes for time to wilt (Table 3). Regression analysis revealed that daily water loss per plant exhibited a significant linear relationship with time to wilt (Fig. 1). This suggests that selection strategies should focus on parameters that reflect the interaction of leaf area and transpiration rate to maximize gain from each selection cycle.

Mean comparisons were carried out by using single-degree of freedom contrast between four logical groupings of genotypes (cultivar, check, breeding selection, and 'Orangeade'). Mean comparisons between the cultivar group and breeding selection group showed that the breeding selections took a significantly longer time to wilt and had a significantly lower transpiration rate than the cultivars (Table 4). Significant differences were observed for leaf area between these groups. However, differences in water loss could not be accounted for by differences in leaf area. For example, RQ-105-2 had significantly (LSD; $P=0.05$ ) more leaf area (103.5 cm') than 'Danlight' $\left(94.3 \mathrm{~cm}^{2}\right)$ and 'Danhill' $\left(80.1 \mathrm{~cm}^{2}\right)$ but had a significantly lower transpiration rate than either cultivar (Table 2). This suggests that differences in water loss and time to wilt are not solely a function of leaf area or plant size.

The same results for these variables were observed when comparing the cultivar group with 'Orangeade' (Table 4). No significant differences were observed between the cultivar group and the check for total water loss, leaf area and time to wilt, however, check had a significantly higher transpiration rate than that observation for cultivars (Table 4). The breeding selections took significantly longer to wilt than 'Orangeade' (Table 4). The check wilted faster and had a significantly higher transpiration rate than breeding selections or 'Orangeade' (Table 4).

The water loss patterns over time differed greatly between cultivars and breeding selections. The water loss from cultivars during the 14-h photo- and 10-h nyctoperiods were higher during the first 4 days of this study than those observed for breeding selections. A comparison of 'Danhill' and RQ-105-5 provide a representative view of the differences in water loss over time between cultivars and selections (Fig. 2). Similar day/night fluctuations in water loss have been reported for cotton (Barrs and Keppler, 1968), sunflower, poplar, and pine (Kramer, 1937). After 4 days, the water loss of cultivars dropped off rapidly but remained higher than those observed for breeding selections. Water loss from breeding selections changed very little over time within the photo- or nyctoperiods. Plants with a higher transpiration rate $\left(\mathrm{mg} \cdot \mathrm{cm}^{-2}\right.$ per $\left.\mathrm{h}\right)$ during the photoperiod had a higher transpiration rate during the nyctoperiod, as well $\left(r^{2}=0.75\right)$. These results suggest that differences in the rate of water loss during the nyctoperiod may be due to differences in cuticle between geno-

Table 4. Mean comparisons between cultivars, breeding selections, 'Orangeade, and check selections for water loss, leaf area, time to wilt and transpiration rate.

\begin{tabular}{lcccc}
\hline \hline Group & $\begin{array}{c}\text { Total water loss } \\
(\mathrm{mg})\end{array}$ & $\begin{array}{c}\text { Leaf area } \\
\left(\mathrm{c} \mathrm{m}^{-2}\right)\end{array}$ & $\begin{array}{c}\text { Time to wilt } \\
(\text { days })\end{array}$ & $\begin{array}{r}\text { Transpiration rate } \\
\left(\mathrm{mg} \cdot \mathrm{cm}^{-2} \cdot \mathrm{h}^{-1}\right)\end{array}$ \\
\hline Cultivar & $83,020 \mathrm{a}^{\mathrm{z}}$ & $116.8 \mathrm{a}$ & $5.11 \mathrm{a}$ & $6.68 \mathrm{a}$ \\
Check & $85,565 \mathrm{a}$ & $93.3 \mathrm{a}$ & $5.25 \mathrm{a}$ & $8.36 \mathrm{~b}$ \\
Orangeade & $82,576 \mathrm{a}$ & $115.5 \mathrm{a}$ & $7.33 \mathrm{~b}$ & $4.20 \mathrm{c}$ \\
Selections & $81,390 \mathrm{a}$ & $84.1 \mathrm{~b}$ & $9.10 \mathrm{c}$ & $4.58 \mathrm{c}$
\end{tabular}

${ }^{\overline{ }}$ Mean comparisons between groups were carried out using single degree of freedom contrasts. Means with different numbers are significantly different at $P=0.01$. 


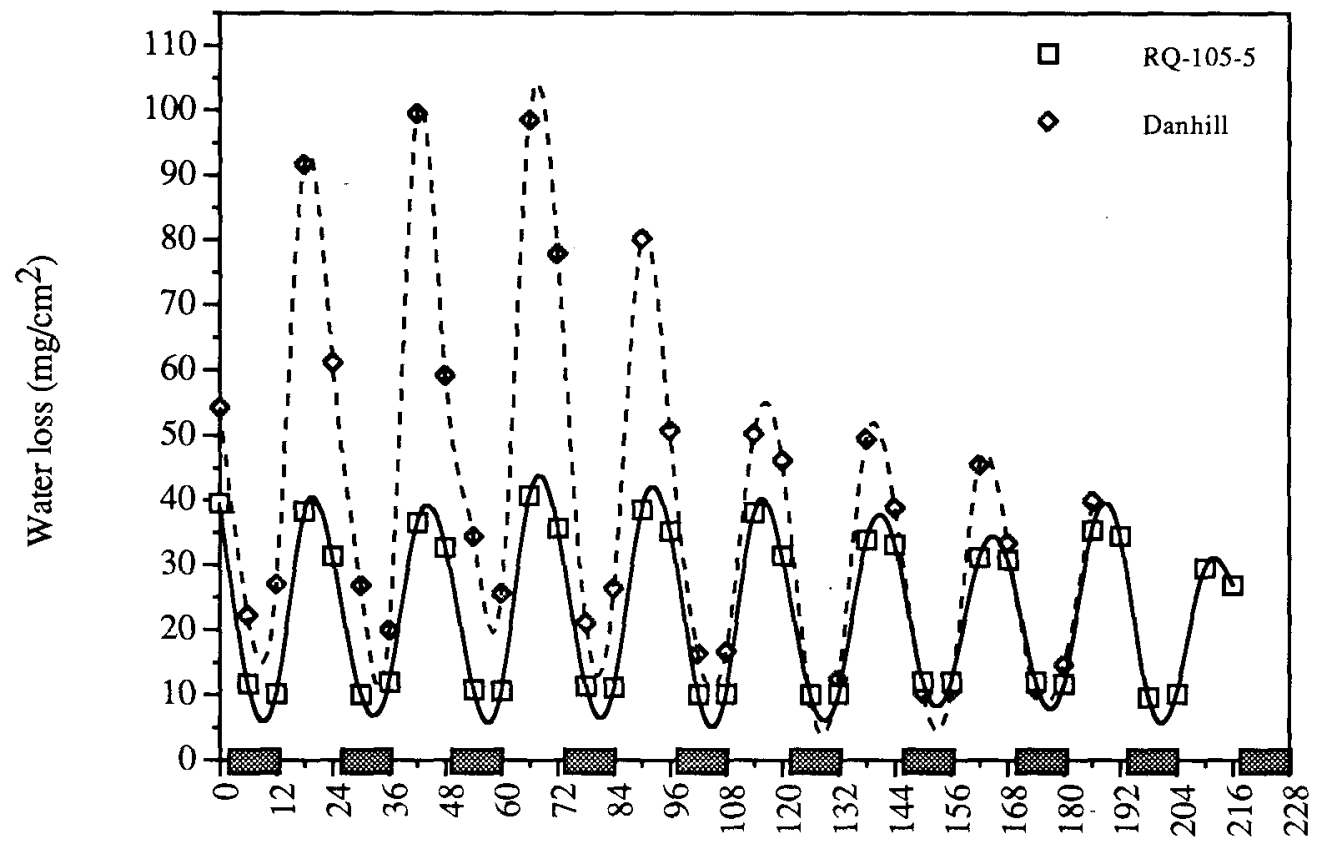

Time (hours)

Fig. 2. Diurnal patterns in transpirational water loss of high and low water loss genotypes of New Guinea impatiens. Time 0 is the time of the first water loss measurement and is $6 \mathrm{~h}$ after the medium was saturated with water. The shaded blocks on the $\mathrm{X}$-axis represent the 10-h nyctoperiods. The intervening time represents the 14-h photoperiods.

types if stomates are closed during the nyctoperiod. Impatiens noli-tangere was observed to have relatively high cuticular transpiration (130.0 $\mathrm{mg} \cdot \mathrm{h}^{-1}$ per $\mathrm{g}$ of fresh weight) compared to other plant species, 0.12 to $47.0 \mathrm{mg} \cdot \mathrm{h}^{-1}$ per $\mathrm{g}$ of fresh weight (Pisek and Berger, 1938). Thus, future research will examine the influence of leaf thickness and cuticle composition and thickness on water loss in New Guinea impatiens.

Stomatal density varied greatly among the genotypes examined in this study (data not shown). However, regression analysis revealed no significant relationship between stomatal density and water loss or time to wilt. This is best illustrated by comparing RQ$105-2$, which had a transpiration rate of $85.7 \mathrm{mg} \cdot \mathrm{cm}^{-2}$ per day and had a stomatal density of 24,533.5 stomates $/ \mathrm{cm}^{2}$, with 'Danlight', which had a 2-fold higher transpiration rate $\left(196.3 \mathrm{mg} \cdot \mathrm{cm}^{-2}\right.$ per day) but a significantly $(P=0.01)$ lower stomatal density $(15,200.1$ stomates $/ \mathrm{cm}^{2}$ ). The size of stomates did not vary significant $\mathrm{y}$ among genotypes (data not shown). The mean length of the long axis of stomata was $24 \mu \mathrm{m}$. Thus, differences in water loss could not be attributed to differences in the number of stomates per unit area of leaf tissue or stomatal size.

Seventy to ninety-two percent of the total water lost per plant from cultivars and checks occurred during the first $96 \mathrm{~h}$ of this study compared to $36 \%$ to $52 \%$ for breeding selections and $57 \%$ for Orangeade over the same time period. This led us to examine whether total water loss after $96 \mathrm{~h}$ (4 days) could be used to predict the time to wilt of cultivars and selections.

Regression analysis showed total water loss after $96 \mathrm{~h}$ was an accurate predictor of time to wilt of New Guinea impatiens genotypes (Fig. 3). Genotypes with the greatest mean water loss after $96 \mathrm{~h}$ had the lowest mean days to wilt, and this relationship was linear for the genotypes tested in this study. Thus, water loss after $96 \mathrm{~h}$ can be used as a reliable selection tool for developing drought-tolerant New Guinea impatiens. This selection method provides an objective and rapid method for identifying superior genotypes with reduced water loss rates.

The cultivar Aurore was used as the female parent for the cross that produced the breeding selection RQ-43-6, and 'Orangeade' was used as the male and female parents of the crosses designated RQ-105 and RQ-79, respectively (Table 1). Thus, we compared the performance of the parents and selected progeny of these crosses and in the case of the 'Orangeade' crosses examined the selected progeny of reciprocal crosses.

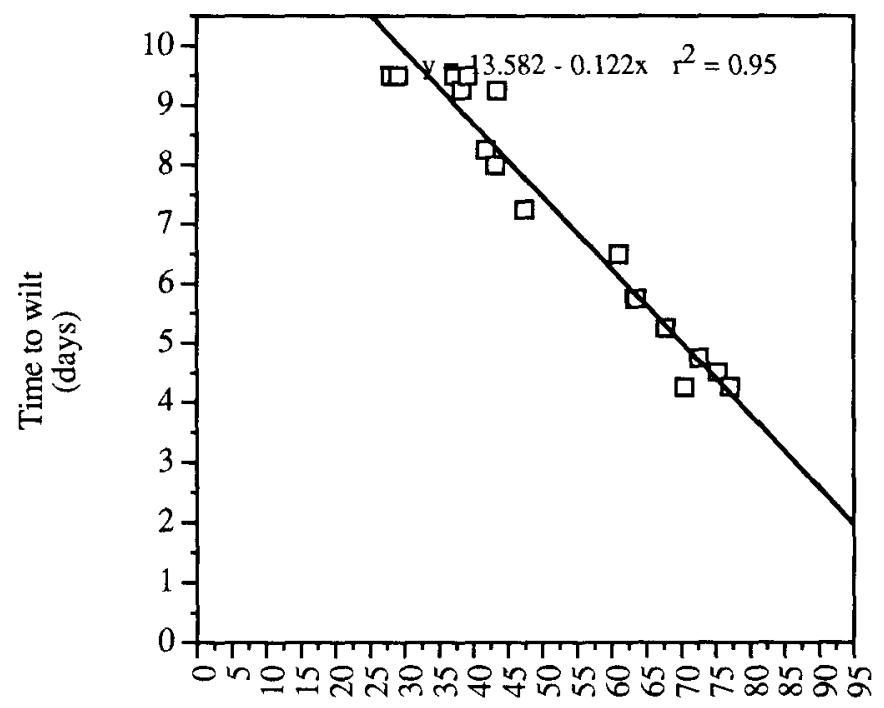

Water loss (g) $96 \mathrm{~h}$ after water was withheld

Fig. 3. Relationship of transpirational water loss over the first $96 \mathrm{~h}$ after water was withheld to the time to wilt for seven cultivars and ten breeding lines of New Guinea impatiens. Transpirational water loss over the $96-\mathrm{h}$ period was calculated for each plant using the following equation: $\mathrm{TWL}=\mathrm{W}_{\mathrm{i}}-\mathrm{W}_{96}$ where TWL is transpirational waterless, $\mathrm{W}$, is initial weight of cutting and growing medium, and $\mathrm{W}_{96}$ is the weight of cutting and medium at time $=96 \mathrm{~h}$. 
Table 5. Mean water loss, leaf area, transpiration rate and time to wilt of parents and progeny of New Guinea impatiens crosses.

\begin{tabular}{lcccc}
\hline \hline Parent/Cross & $\begin{array}{c}\text { Water loss } \\
(\mathrm{g} / \mathrm{day})^{\mathrm{z}}\end{array}$ & Leaf area $\left(\mathrm{cm}^{2}\right)$ & $\begin{array}{c}\text { Transpiration rate } \\
\left(\mathrm{m} \mathrm{g} \cdot \mathrm{c} \mathrm{m}^{-2} \cdot \mathrm{h}^{-1}\right)^{\mathrm{y}}\end{array}$ & $\begin{array}{c}\text { Time to wilt } \\
(\mathrm{days})\end{array}$ \\
\hline Aurore & $13.3 \mathrm{a}$ & $102.0 \mathrm{a}$ & $6.6 \mathrm{a}$ & $5.75 \mathrm{a}$ \\
RQ-43 & $10.2 \mathrm{~b}$ & $88.8 \mathrm{~b}$ & $5.0 \mathrm{~b}$ & $8.25 \mathrm{~b}$ \\
Orangeade & $11.0 \mathrm{a}$ & $115.5 \mathrm{a}$ & $4.3 \mathrm{a}$ & $7.25 \mathrm{a}$ \\
RQ-105 & $8.3 \mathrm{~b}$ & $90.7 \mathrm{~b}$ & $4.0 \mathrm{~b}$ & $9.50 \mathrm{~b}$ \\
RQ-79 & $9.2 \mathrm{c}$ & $73.3 \mathrm{c}$ & $5.9 \mathrm{c}$ & $9.25 \mathrm{~b}$
\end{tabular}

${ }^{ }$Mean comparisons between parent and selections were carried out using single degree of freedom contrasts. Means with different numbers are significantly different at $P<0.01$.

'Transpiration rate was calculated for each plant by dividing total water loss by leaf area $\left(\mathrm{cm}^{2}\right)$ and time to wilt (h) and the numbers in the table are the means of the 12 plants.

The selection RQ-43-6 lost significantly less water, had significantly less leaf area per plant and a lower transpiration rate, and took longer to wilt after water was withheld than its maternal parent, 'Aurore' (Table 5). Progeny from RQ-105 and RQ-79 crosses lost significantly less water, had significantly less leaf area per plant and lower transpiration rates, and took longer to wilt than their parent, 'Orangeade' (Table 5). This indicates that sufficient variability exists among cultivars to reduce water loss by conventional breeding and selection practices using cultivars as parents.

The results of this study demonstrate that sufficient variability exists in New Guinea impatiens to make significant advances in breeding for reduced water loss. After one cycle of selection, daily water loss was reduced by as much as $48 \%$ over the commercial cultivar with the lowest daily water loss, Thelca, and by as much as $30 \%$ over 'Orangeade'. Gain from selection may decrease as populations are improved by hybridization and differences among progeny are less apparent. Thus, the simple selection method, water loss from cuttings in rock-wool, developed as a result of this study, will provide a means of discerning small but significant differences in water loss that will become critical as elite lines are developed in the future. These results also show that a qualitative selection method based on plant appearance can be useful as an early selection method for identifying plants with reduced water loss for further testing.

Reduced water loss on a per-plant basis was related to transpiration rate and leaf area. Selection for factors that reduce transpiration combined with selection for smaller leaves may result in more drought-tolerant New Guinea impatiens. However, reduced leaf size may affect the aesthetics of this plant and thus its marketability y. Plants selected from our breeding lines had significantly less leaf area than commercial cultivars but had sufficient foliage to maintain the aesthetic appeal of the plant. This factor must be a priority during selection of drought-tolerant plants for cultivar development.

\section{Literature Cited}

Armstrong, R.J. 1974. An impatiens circus the Longwood New Guinea hybrid impatiens. Amer. Hort. 53: 14-18.

Barrs, H.D., and B. Keppler. 1968. Cyclic variations in plant properties under constant environmental conditions. Physiol. Plant. 21:7 11-7 13.

Begg, J.E. 1980. Morphological adaptations of leaves to water stress, p. 3 42. In: T.C. Tumerand P.J. Kramer (eds.). Adaptations of plants to water and high temperature stress. Wiley, New York.

Ehleringer, J. 1980. Leaf morphology and reflectance in relation to water and temperature stress, p. 295-308. In: T.C. Turner and P.J. Kramer (eds.). Adaptations of plants to water and High temperature stress. Wiley, New York.

Kaczperski, M., and W.H. Carlson, 1989. Producing New Guinea impatiens. A commercial grower's guide. Michigan State Univ. Coop. Ext. Serv. Bul. E-2179:1-4.

Kramer, P.J. 1937. The relation between rate of transpiration and rate of absorption of water in plants. Amer. J. Bet. 24:10-15.

Mack, C. 1989. Spring showcase. California Grower 13:20-22.

Martin, T. 1984. New Guinea impatiens. Horticulture 63(8):32-36.

Pisek, A. and E. Berger. 1938. Kutikuläire transpiration und trockenresistenz isolierter blatter und sprosse. Planta 28:124-155.

Winters, H.F. 1973. New impatiens from New Guinea. Amer. Hort. 52:16-22. 